\title{
Information overload and lecturer mistakes during engineering course organization
}

\section{Kristina Tihomirova ${ }^{1}$, Linda Mezule ${ }^{1}$}

${ }^{1}$ Department of Water Engineering and Technology, Riga Technical University, Latvia.

\begin{abstract}
It has been observed that huge amount of information received from teachers can create a feeling of overload for students. Selection of modern teaching methods do not always help to solve this issue. To identify the link between information overload at various study course organization models (regular, advanced and super-advanced), various lecturer types have been described. These include apathetic, formal, teacher-centred egoist, student-centred chaotic lecturer and activist. The results demonstrated that course organization in engineering studies is closely linked to the personality of the lecturer. Successful course organization is based on good time management, selection of appropriate amount of information. In advanced and superadvanced courses regular communication between lecturers and experts in practice is favoured. At the same time selection of adequate amount of study material based on the general knowledge level of the students is required. To achieve the goal, each lecturer should evaluate the level of information required and the overall interest level of students in the course topic on a regular basis before the beginning of the course.
\end{abstract}

Keywords: Information; overload; course organization; time management. 


\section{Introduction}

Nowadays to develop better communication and perception of the academic topics, various teaching techniques, such as Flipped Classroom (pre-preparations of topic before the lesson), Design Thinking (based on workshops, communications and master classes), Self-learning (use of modern IT systems, such as Mind Map to expand the ability in students to memorize large reams of text), Gamification (learning thought the games), Social Media (additional communication aimed on motivation and interest growing), different Online Learning Tools (interactive and dynamic classroom) have been recommended: Santos (2018). At the same time "fast living" lifestyle with constant streams of new information significantly affects the physiological state of individuals: Parkins (2004). Often information quantity and constant changes make people feel like their lives is in chaos and can evoke negative emotions about the obtained information. Huge amount of information in personal life (books, TV, emails and etc.) and studying process (lessons, articles, laboratory works, projects and etc.) can create a feeling of overload for also students: Rentfrow et al. (2011) and subsequently reduce the overall academic performance of the student: Suhaimi and Hussin (2017).

Institute of Heat, Gas and Water technologies is a part of Faculty of Civil Engineering at Riga Technical University (156-year-old state founded non-profit and accredited higher educational establishment of the Republic of Latvia). It consists two departments (Department of Water Engineering and Technology (DWET) and Department of Heat, Gas and Technology) that provide all level higher education (Bachelor professional, Master academic and Doctoral studies) and carry out research in the field of heating, ventilation, airconditioning, water and wastewater treatment and distribution systems, water distribution network and sewage collection systems. The study programme of the institute was modified and optimised according to the industrial tendencies throughout 26 academic years. Teaching methods are aimed to grow practical understanding, skills and knowledge in the field of heat, gas and water engineering systems and its better management. Over the past 3 years, the team of DWET has fundamentally changed the structure of several courses and created a system that is comfortable for lecturers and more interesting for students. This includes multiple lecturer approach in a single course to ensure adequate replacement, better competences and more active engagement of students. At the same time in multiple courses low or no modernisation has been performed and classical academic format is retained.

Within this paper we aim to demonstrate that mistakes in the study course organization are strongly linked with the personality of the academic personnel and can cause information overload feeling in students if wrongly managed. 


\section{Methodology}

Admission to studies at the RTU takes place in accordance with Latvian legislation, that provided that any Latvian and EU citizen can enter the studies. The regular work in DWET is performed by 15 lecturers and number of students varies from 20 to 32 in each study year. To identify the emotional opinion of students about the courses in RTU DWET, questionnaires are being sent out to all students after each study semester. Based on voluntary principle the students evaluate the quality of courses and work of lecturers from 1 (low quality) to 5 (high quality) in a standardized online system designed by RTU. Lecturers can read the summary and the number of completed questionnaires. General observations are that student activity is low and often the number of completed questionnaires and comments may be " 0 " or "1". Within this paper the results from questionaries' from 32 respondents of 2018/2019 study year were used. The feedback in terms of received comments from students reached at least $50 \%$ from the overall questionnaires received.

\section{Observations and disscusions}

\subsection{Course organization models}

Every new student enrolled in a university already has some basic knowledge. During the studies they are guided through various education models in a particular program depending on the instruction style of particular academic staff: Hewes (2017). Education models can be regular (surface or apathetic learning approach), advanced (or strategic) or super advanced (or deep): Banerjee et al. (2019). The described course models can be found in each educational institution, as well as in DWET of RTU.

In a regular course the lecturer teaches students through memorization and recitation techniques, and not by developing their critical thinking with problem solving and decisionmaking skills: Snyder and Snyder (2008). This model is based on the formal learning and a teacher-student relationship: lessons, calculations, tests and final examination. Usually the courses are well structured and synchronised in terms of learning objectives, learning time or learning support: Rogers (2014).

During an advanced course, the selected teaching model is more interacting. The students learn through group participation, workshops and gaming techniques. These parts of the course are outside the formal learning system and similar to non-formal learning. It is also well structured. Unlike in regular course, advanced course and respective teaching method promotes the development of critical thinking skills, problem-solving abilities, communication skills: Duch et al. (2001), Klegeris and Hurren (2011), Oprea (2014). In this model the students are the active participants of the learning process. 
Super advanced or deep courses include informal study through the experience of day-to-day situations, non-formal learning and also accelerated learning that include a variety of media, techniques, guest lecturers, supervisors from specialization sector or mentors: Rogers (2014). This teaching method is comparable to student-centred approach, where both teacher and students play active role: Keiler (2018). This model provides more informal environment and students' work through various projects, presentations of ideas or discussions. In comparison with the traditional learning approaches accelerated learning is more flexible and open for students. They all are involved in the learning process; the learning process is more enjoyable and productive.

Thus, the course organisation model till some extent is dependent on the level of study and subject, self-motivation of the students and type of the lecturer.

\subsection{Type of the lecturer}

Various types of teachers or lecturers have been described in the literature as well as they can be identified in each educational institution. Usually the working style of the lecturer can't be controlled. It is formed over time and depends on the individual characteristics of the person and life experience. Some basic types of lecturers are summarized in Table 1.

All described course models and types of lecturers are based on other studies, but up to date the linkage between information overload and lecturer type in engineering courses has not been described.

\subsection{Information overload and lecturer types in engineering courses}

Work area of the apathetic lecturer is very clear. Usually the lecturer works with standardised programme over several years, uses the same books as basis for course information, precise and simple exercises to learn the rules. As a result, students meet requirements of the course, gain relatively good theoretical knowledge and pass the exam if they successfully learned all the theory. Nevertheless, this type of lecturer fully supports the requirements of basic/regular courses and provides adequate amount of knowledge. At the same time the main feedback from students: "boring lectures" (rating varied from 1 to 3 in $50 \%$ of the questionnaires).

The work of the formal lecturer is based on the same strategy (standardised programme). The difference with the previous one is that formal learning lecturer includes some laboratory works to course and theoretical engineering projects, for example, calculation of water treatment plant with the necessary methodological instructions. There is a try to make the course more advanced, but due to insufficient clarification of goals and low communication with the students this is not always possible. The rating varied from 4 to 5 in $75 \%$. 
Table 1. Main types of lecturers.

\begin{tabular}{|c|c|c|c|}
\hline & Title & Type & Description \\
\hline 1 & Activist & $\begin{array}{c}\text { Student } \\
\text { centered } \\
\text { lecturer }\end{array}$ & $\begin{array}{l}\text { (+) Expert in their field, have demonstrated excellence in } \\
\text { more than one academic specialty, has excellent } \\
\text { communication skills with future professional or student. He } \\
\text { reads reviews of his work and plans lessons. This lecturer } \\
\text { follows industry trends and is qualified to lecture and/or } \\
\text { conduct research in a particular subject. } \\
(-) \text { Very busy person, overloaded time graphs. }\end{array}$ \\
\hline 2 & $\begin{array}{l}\text { Chaotic } \\
\text { lecturer }\end{array}$ & $\begin{array}{l}\text { Student } \\
\text { centered } \\
\text { lecturer }\end{array}$ & $\begin{array}{l}\text { (+) Very similar to previous type. } \\
\text { (-) Every year this lecturer adds new activities to the } \\
\text { course as result course becomes overloaded with } \\
\text { information. Each activity is interesting, but due to } \\
\text { overloading, students do not complete any of them. }\end{array}$ \\
\hline 3 & Egoist & $\begin{array}{l}\text { Teacher- } \\
\text { centered } \\
\text { lecturer }\end{array}$ & $\begin{array}{l}\text { (+) Qualified to lecture and has great time management } \\
\text { system. He has his own communication system with students, } \\
\text { regularly collects and reads feedbacks from them. This } \\
\text { lecturer has demonstrated excellent knowledge in theory. } \\
\text { (-) Has demonstrated low knowledge in practice. He has low } \\
\text { contact with colleagues, usually works alone. }\end{array}$ \\
\hline 4 & $\begin{array}{l}\text { Formal } \\
\text { lecturer }\end{array}$ & $\begin{array}{l}\text { Teacher- } \\
\text { centered } \\
\text { lecturer }\end{array}$ & $\begin{array}{l}\text { (+) Follows industry trends and is qualified to lecture. He } \\
\text { has low contact with student. } \\
\text { (-) He reads reviews of his work and makes changes in } \\
\text { courses without specific emotions. }\end{array}$ \\
\hline 5 & $\begin{array}{l}\text { Apathetic } \\
\text { lecturer }\end{array}$ & $\begin{array}{l}\text { Teacher- } \\
\text { centered } \\
\text { lecturer }\end{array}$ & $\begin{array}{l}\text { (+) Has demonstrated good knowledge in theory. } \\
\text { (-) A person tired of the job and annoying to the students. } \\
\text { The lecturer doesn't want to change anything and works only } \\
\text { with fundamental theory. }\end{array}$ \\
\hline
\end{tabular}

Source: Quinn and Carl (2015), Hill-Jackson et al. (2019), Dahlbeck (2017), Shaari et al. (2014), Mitchell (2013).

In advanced courses more activities are present to grow practical understanding, skills and knowledge in the field of water and wastewater management and engineering systems. When the course is coordinated by teacher-centred lecturer egoist, the course is more theoretical.

The students that pass the exam successfully have great theoretical background in the specific field, but to become experts in the field, they require more practice. Students give positive 
feedback of the lecturer`s work and show interest in the field (rating varied from 4 to 5 in 75 $\%)$, however, negative feedback from industry has been received, like "The student is stuck in theory" or "Student's knowledge is disconnected from reality" (personal communication with representatives from water and wastewater industry, $n=5$ ). To solve this limitation, practical excursions, consultations and communications with representatives and experts from industry should be organised more frequently in these courses.

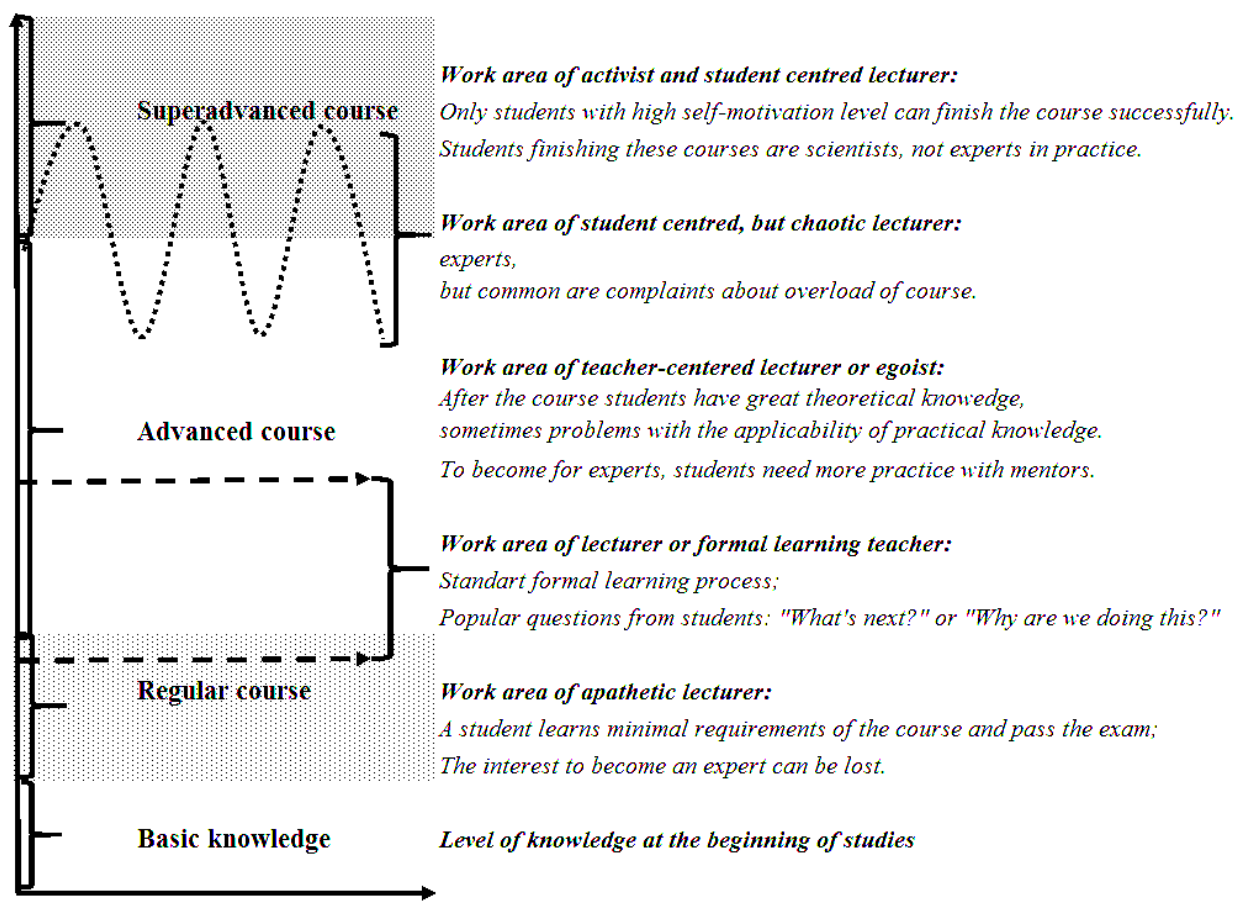

Figure 1. Connection between course level and types of lecturers.

If the advanced course is organised by a chaotic lecturer different visiting professors and workshops are organised on a regular basis. Due to the enormous excitement of his/her work, the lecturer tries to lead both theory, course and laboratory works, invite visiting lecturers not only from other universities, but also from industrial companies, to give students the opportunity to get acquainted with the practical side of the field. The worst-case scenario occurs when several complex courses are run in parallel. A lack of communication between the lecturers is common. Both overload the students with information. As result the feedback is negative: "Too much information", "It isn't clear, why we are doing these work" or "Several calculation projects in one semester is too hard" (rating varied from 3 to 5 in 100 $\%)$. Moreover, problems with time management have been observed. 
An activist and student-centred lecturer spends more work in the course organisation. The time management and structuration of the course is very important for this type of lecturer. Sometimes the courses are realised in cooperation with lecturers from other universities. The students acquire deep theoretical knowledge and several specific topics are covered during the course. Doctoral and Master`s level students usually write positive reviews and show interest in the science provided by the lecturer. However, the type of course is suitable for those who plan to become scientists and will not practice in engineering systems. In case of undergraduate students, the negative comments are received about this type of lecturer: "Too much information" or "Too hard information". At the same time the overall rating is high (4 to 5 in $100 \%$ ) due to the quality of the courses and overall lecturer interest.

Based on the identified lecturer types, their work area of the respective courses can be generated (Figure 1). Apparently, the knowlegefull apathetic lecturers should focus on regular courses providing and strengthening basic knowledge to all levels of students with various interest in the field. At the same time the lecturer - activist should limit their skills to super-advanced courses that usually gather students interested in the specific topic and ready to work more than regulated. Other lecturers can offer some more flexibility in terms of courses, however, they have to keep constant follow up in their teaching style and outcomes.

\section{Conclusions}

Successful course organization is based on good time management, regular communication between lecturers and experts in practice and constant notice of the student ability level (in academic level and general interest).

Theorical courses can be applicable only to grow basic knowledge about engineering systems, not experts in practice. At the same time use of advanced and super-advanced courses for undergraduate students should be carefully selected and monitored to ensure balance between the activity of the lecturer and general student interest in the topic.

The effect of the information overload can be minimized by finding the synergy between the lecturer type and course level. Each lecturer before the beginning of the course should critically evaluate the level of information students require and the overall interest of the students in the specific topic.

\section{References}

Banerjee, Y., Akhras, A., Khamis, A.H., Alsheikh-Ali, A, Davis, D. (2019). Investigating the Relationship Between Resilience, Stress-Coping Strategies, and Learning Approaches to Predict Academic Performance in Undergraduate Medical Students: Protocol for a Proofof-Concept Study. Journal of Medical Internet Research Protocols, 8(9), e14677. doi: $10.2196 / 14677$. 
Dahlbeck, J. (2017) The egoistic teacher: educational implications of Spinoza's ethical egoism. Ethics and Education, 12(3), 304-319. doi: 10.1080/17449642.2017.1343653.

Duch, B. J., Groh, S. E, Allen, D. E. (Eds.). (2001). The power of problem-based learning. Sterling. VA: Stylus.

Hewes, B. (2017, March 25). The skill, will, and thrill of Project Based Learning. Message posted to https://biancahewes.wordpress.com

Hill-Jackson, V., Hartlep, N. D., \& Stafford, D., (2019). What Makes a Star Teacher: 7 Dispositions That Support Student Learning.VA: ASCD.

Keiler, L.S. (2018). Teachers' roles and identities in student-cantered classrooms. International Journal of STEM Education, 5(34), 1-20. doi: 10.1186/s40594-018-01316.

Klegeris, A., Hurren, H. (2011). Impact of problem-based learning in a large classroom setting: student perception and problem-solving skills. Advances in Physiology Education, 35, 408-415. doi: 10.1152/advan.00046.2011.

Mitchell, M. (2013). Teacher Enthusiasm: Seeking Student Learning and Avoiding Apathy. Journal of Physical Education, Recreation \& Dance, 84, 19-24. doi: 10.1080/07303084.2013.779536.

Oprea, C. L. (2014). Interactive and creative learning of the adults. Procedia: Social and Behavioural Sciences, 142, 493 -498. doi: 10.1016/j.sbspro.2014.07.654.

Parkins, W. (2004). Out of Time: Fast Subjects and Slow Living. Time \& Society, 13(2-3), 363-382. doi: 10.1177/0961463X04045662.

Quinn, R. \& Carl, N. (2015). Teacher activist organizations and the development of professional agency. Teachers and Teaching, 21, 1-14. doi: 10.1080/13540602.2015.1044331.

Rentfrow, P. J., Goldberg, L. R., \& Zilca, R. (2011). Listening, watching, and reading: the structure and correlates of entertainment preferences. Journal of personality, 79(2), 223 258. doi: 10.1111/j.1467-6494.2010.00662.x.

Rogers, A. (2014). The base of the iceberg: Informal learning and its impact on formal and non-formal learning. Opladen/Berlin/Toronto: Barbara Budrich Publishers.

Santos, D. (2018, September 17) Teaching Techniques You Should Know! Message posted to https://www.goconqr.com/en/examtime/blog

Shaari, A. S., Yusoff, N. M., Ghazali, I. M., Osman, R. H., \& Dzahir, N. F. M. (2014). The relationship between lecturers' teaching style and students' academic engagement. Procedia - Social and Behavioural Sciences, 118, 10-20. doi: 10.1016/j.sbspro.2014.02.002.

Snyder, L. G., \& Snyder, M. J. (2008). Teaching critical thinking and problem-solving skills. Delta Pi Epsilon Journal, 50(2), 90-99.

Suhaimi, F. A., \& Hussin N. (2017). The Influence of Information Overload on Students' Academic Performance. International Journal of Academic Research in Business and Social Sciences, 7 (8), 760-766. doi: 10.6007/IJARBSS/v7-i8/3292. 